\title{
Antrum Pylori
}

National Cancer Institute

\section{Source}

National Cancer Institute. Antrum Pylori. NCI Thesaurus. Code C12259.

The initial part of the pyloric canal of the stomach. This site contains endocrine cells that produce gastrin and somatostatin. 